\title{
Bibliometric analysis of peer-reviewed literature in transgender health (1900 - 2017)
}

Waleed M. Sweileh

\begin{abstract}
Background: Transgender community is marginalized and under-researched. Analysis of peer-reviewed literature in transgender health is needed to better understand health needs and human rights of transgender people. Therefore, the aim of this study was to analyze global research activity in transgender health published in peer-reviewed journals.

Methods: Peer-reviewed documents in transgender health were retrieved using Scopus database. VOSviewer was used to map frequently encountered author keywords while ArcGIS 10.1 was used to map the geographical distribution of the retrieved documents. Most active countries, institutions, and authors were presented. The study period was set from 1900 to 2017.

Results: In total, 5772 peer-reviewed documents were obtained. English $(5008 ; 86.8 \%)$ was the most frequently encountered language. A dramatic increase in the number of publications was seen in the last decade. The retrieved documents had an average of 12.1 citations per document and $h$-index of 92 . Most frequently encountered author keywords were Human immunodeficiency virus infection and acquired immune deficiency syndrome (HIV/AIDS), mental health, and discrimination. Authors from 80 different countries contributed to publishing the retrieved documents. Publications originated mainly from Northern America, certain European countries, Australia, and Brazil. Professor Gooren, L.J.G. was the most active author in this field with 104 (1.88\%) publications. Top active authors were in the fields of endocrinology, plastic surgery, psychiatry/psychology, public health, and sexology. Five of the top ten active authors were from the USA, three were from the Netherlands, and two were from Belgium. The most active institution was the VU University Medical Center (Netherlands) (184; 3.2\%) followed by the University of California, San Francisco (USA) (157; 2.7\%). The International Journal of Transgenderism was most active $(284 ; 4.9 \%)$ in publishing articles in transgender health. However, documents published in the American Journal of Public Health had the highest impact with 53.5 citations per article.
\end{abstract}

Conclusion: There was a noticeable growth of research in transgender health in the last decade. Researchers from different world regions need to get involved in health and human rights research of transgender community.

Keywords: Transgender, Health, Bibliometric analysis, Human rights

\footnotetext{
Correspondence: waleedsweileh@yahoo.com

Department of Physiology, Pharmacology/Toxicology, Division of Biomedical

Sciences, College of Medicine and Health Sciences, An-Najah National

University, Nablus, Palestine
}

(c) The Author(s). 2018 Open Access This article is distributed under the terms of the Creative Commons Attribution 4.0 International License (http://creativecommons.org/licenses/by/4.0/), which permits unrestricted use, distribution, and reproduction in any medium, provided you give appropriate credit to the original author(s) and the source, provide a link to the Creative Commons license, and indicate if changes were made. The Creative Commons Public Domain Dedication waiver (http://creativecommons.org/publicdomain/zero/1.0/) applies to the data made available in this article, unless otherwise stated. 


\section{Background}

The term "transgender" describes a wide range of persons who are present across different cultures and countries [1]. The opposite term to transgender is "cisgender" which is a description for people whose gender identity matches the sex that they were assigned at birth [2]. Unfortunately, no global and updated data on the number of transgender persons are available, but there are approximately 1 million transgender adults living in the United States of America (USA) [3, 4] and approximately 9.0 million living in Asia and the Pacific regions $[5,6]$. Estimates from different world regions indicate that the prevalence of transgender identity varies between $0.1 \%$ and $1.1 \%$ of reproductive age adults [7].

Transgender people face several social and health challenges such as violence, stigma, discrimination, social rejection, and inadequate specialized healthcare facilities $[8,9]$. There are tremendous efforts in many developed countries to recognize the human rights of transgender persons [10-12]. Part of the action plan to endorse transgender community was to get researchers and academics engaged in research activity pertaining to health needs and challenges facing transgender persons. The scientific community can endorse the transgender community in several ways. For example, The Lancet had issued a series of comments and reports on transgender health that aimed to increase awareness and to promote better health services for the transgender community [8, 9, 13-18]. Several specific journals have been launched to endorse health and human rights of lesbian, gay, bisexual, and transgender people (LGBTQ). The letter "Q" in the LGBTQ refers to those who identify as queer or are questioning their sexual identity [19].

The Institute of Medicine considers transgender persons as neglected, marginalized, understudied, and in critical and urgent need of research regarding their health status and health needs $[1,8]$. Transgender individuals are usually researched within LGBTQ community. However, transgender people are different from lesbians, gays, and bisexuals and might have different health and life experiences than gay and lesbians [20]. In light of the large numbers of transgender persons and the international efforts to endorse and strengthen human rights of neglected and marginalized groups, analysis of global research activity in transgender health becomes important [21-29]. Therefore, the aim of this study was to assess peer-reviewed literature in transgender health and present the results in bibliometric tables and maps. Research in transgender health is an essential component in recognition of this community and its health needs and health rights. The community of transgender individuals is seeking social support from all communities including those in academia and research scientist. Findings of the current bibliometric analysis could be used to advocate the human and health rights of transgender people particularly in countries with limited research activity in this field. Furthermore, bibliometric data obtained from the current study could be used by international health organizations and health activists to encourage politicians and health policymakers to adopt issues related to transgender health and include these issues in their political agendas and campaigns.

\section{Methods \\ Database}

In bibliometric studies, a large database is used to retrieve relevant documents for subsequent analysis. This study was conducted using SciVerse Scopus which has been used in several previously published bibliometric studies [30-37]. The choice of Scopus was based on the advantages it has over Web of Science and Pubmed [38]. The duration of this study was set from 1900 to 2017. Furthermore, no language restriction was made in retrieving the relevant documents. Articles indexed in Scopus must have an English abstract, and therefore, the relevancy of any retrieved document could be confirmed by reading the English abstract regardless of the original language of the document.

\section{Search strategy and inclusion criteria}

Search strategy and keywords used were illustrated in (Additional file 1). Keywords used were partially obtained from published systematic reviews in transgender health [9, 39, 40]. The search strategy was based on both title search and journal search. In the title search, all documents with the following keywords in the title were retrieved:

Title(enby or queer or transfeminine or genderqueer or bigender or pangender or genderfluid or agender or "transgender*" or "transsexual*" or "trans men" or "trans women" or "gender dysphoria" or "gender nonconform*" or "sex* reaassig*" or "gender reassign*" or transvest" or travesty or "koti" or "hijra" or "mahuvahine" or "mahu" or "waria" or katoey or "cross dresser" or "bantut" or "nadleehi" or "berdache" or "xanith" or "gender dysphori*" or "gender incongruen*" or "gender non-conform*" or "gender affirm* surg*" or "gender variant" "FTM individ"*" or "MTF individ*" or transgender* or "trans men" or transmen or transman or "trans man" or"trans male" or transmale or "trans women" or transwomen or transwoman or "trans woman" or "trans female" or transfemale or "trans masculine" or transmasculine or transsex* or transvest* or "sex reassignment" or "gender reassignment" or "gender change" or "sex change")) or((Title("gender minorit" $\left.{ }^{*}\right)$ and title-abstract-key(transgender* or transsex $\left.\left.^{*}\right)\right)$ ) or ((Title("female to male" OR "male to Female" or M2F or F2M) and title-abstract-key(transgender or transsex*)) ) or ((Title("two spirits" or "non binary" or 
cisgender) and title-abstract-key (transgender or transsexual*)))

In journal search, all documents published in journals having the keyword "transgender" were retrieved under the condition that the document has the term transgender or transsexual in the title and/or abstract. The search looked like this: (Journal name (transgender*) and titleabstract-key (transgender or transsex* OR M2F or F2M)).

The results obtained from the strategies stated above were combined.

\section{Exclusion criteria}

1. Documents published in non-health related journals such as "English teaching" or "English lite*" or Estudios or literature or geography were excluded.

2. Documents within the subject areas of computer, mathematics, physics, chemistry engineering, material science, agriculture, and veterinary were also excluded.

3. Documents with keywords pertaining to plants or animals or birds such as plant or flower or animal or fly or birds or vet* or butterf* were also excluded.

4. Only documents published in peer-reviewed journals were retrieved and analyzed. Conference abstracts/papers published in peer-reviewed journals were included in the analysis while conference abstract not published in peer-reviewed journals were not included in the study. Books and book chapters were excluded.

The asterisk is used in the search strategy as a wildcard to retrieve any possible related keyword while the quotation marks were used to retrieve the exact phrase written within the quotation.

\section{The validity of search strategy}

In this study, the validity of the search strategy was confirmed by two methods. In the first method, the author manually reviewed the top 200 cited articles to make sure that all these articles were relevant to the theme of the study. In the second method, the number of articles for each of the top ten active authors was retrieved manually and compared with the number obtained through the search strategy. The results of the comparison showed strong and significant correlation $(r=0.96 ; p<0.01)$ indicative of the high validity of research method.

\section{Bibliometric indicators}

Retrieved documents were analyzed and results were presented as top ten active countries, authors, institutions, and journals. Data pertaining to active countries, journals, authors, and institutions are exported from Scopus to Excel program for tabulation. It should be noted here that Scopus counts the number of publications for each country based on author affiliation regardless of the position of the author in the author list. Therefore, there is a potential overlap in the number of publications assigned for each country. For example, a document with two authors from two different countries is counted once for each country. Same applies to data pertaining to most active authors and institutions.

\section{Bibliometric mapping}

Author keywords were visualized using VOSviewer program [41] which is available for free download [42] along with its technical manual [43]. In VOSviewer, author keywords are mapped based on a minimum number of occurrences. The size of the node for each keyword in the map represents its frequency of occurrence in the retrieved documents. Larger node size indicated a high frequency of occurrence. VOSviewer can also be used to do overlay visualization in which keywords with yellow color represent the most recently used author keywords. The geographical distribution of publications was mapped using ArcGIS 10.1 software [44]. This software is available at the Faculty of Engineering at An-Najah National University and available for staff use. In ArcGIS, different colors are given to various world regions. Map regions with white color represent countries with missing data or no research contribution to the field being investigated. In the current study, the impact of publications was measured using Hirsch - index ( $h$-index) which depends on the number of citations of the publication with higher $h$-index indicating higher impact [45].

\section{Ethical consideration}

No human subjects were involved in this study and, therefore, no approval from institutional review board was required.

\section{Results}

Types of documents, languages, and subject areas In total, 5772 documents were retrieved. The majority (4462; 77.3\%) of retrieved documents were research articles followed by review articles $(635 ; 11 \%)$, letters $(209 ; 3.6 \%)$, notes $(138 ; 2.4 \%)$, editorials $(114 ; 2 \%)$, conference papers (73; $1.3 \%)$, and short surveys $(65,1.1 \%)$. At the time of writing this manuscript, there were $76(1.3 \%)$ documents in press and were of unknown types. English was the main language $(5008 ; 86.8 \%)$ of the retrieved documents followed by German (239; 4.1\%), French (183; 3.2\%), Spanish (88; $1.5 \%)$, Portuguese $(69 ; 1.2 \%)$, and Polish $(41 ; 0.7 \%)$. The majority of retrieved documents were published in journals indexed under the subject area of medicine (3436; 59.5\%), followed by those indexed in social sciences $(1849 ; 32.0 \%)$, psychology (1213; 21.0\%), and nursing (337; 5.8\%) Due to 
indexing of some journals in more than one subject area, the total percentage of subject areas exceeded $100 \%$.

\section{Growth of publications}

The oldest published article in transgender health appeared in "Zeitschrift für die gesamte Neurologie und Psychiatrie" journal in 1913 [46]. This article discussed the neurological and psychiatric background of transvestism. The number of publications continued to grow slowly from 1913 to 2004 (Fig. 1). During this period the number of publications remained below 100 documents per year. A dramatic increase in the number of publications was observed after 2005. The maximum number of publications was recorded in 2017. The total number of documents published from 2005 to 2017was 3836 (58.5\%). The growth rate of publications from 2015 to 2016 was $30.9 \%$ and that from 2016 to 2017 was $27.5 \%$.

\section{Citation analysis}

The retrieved documents received 69910 citations, an average of 12.1 citations per document. The $h$-index of the retrieved documents was 92 . The range of citations obtained was from 0 to 524 . The article that received the highest citations was published in International Journal of Transgenderism in 2012. This article provided clinical guidance for health professionals on how to assist transgender, transsexual, and gender non-conforming people in a safe and effective way [47]. Table 1 shows the list of highly cited articles. The list included seven research articles and three review articles. Three of the highly cited articles were published in Journal of Homosexuality. The list included articles that discussed aspects in the field of mental health, infectious diseases, endocrinology, neurology, and public health of the transgender community.

\section{Mapping author keywords}

Health-related author keywords with minimum occurrences of 10 were visualized and presented in network visualization map (Fig. 2 a). The most frequently encountered author keywords were grouped into seven different clusters shown in different colors. The most prominent clusters were those pertaining to HIV and other sexually transmitted diseases (STD), mental health, social acceptance and human rights, psychotherapy, and counseling. Overlay visualization, which shows the time of appearance of most frequently author keywords, indicated that keywords such as stigma, health disparities, health services, resilience, HIV prevention, and social support were the most recently used author keywords (Fig. 2 b).

\section{Geographical distribution of retrieved documents}

Authors from 80 different countries contributed to publishing the retrieved documents. Geographical distribution of the retrieved documents was based on the country affiliation of all authors participating in publishing the retrieved articles. Retrieved documents originated mainly from Northern America, certain European countries, Australia, and Brazil (Fig. 3). The African region, Middle East, and

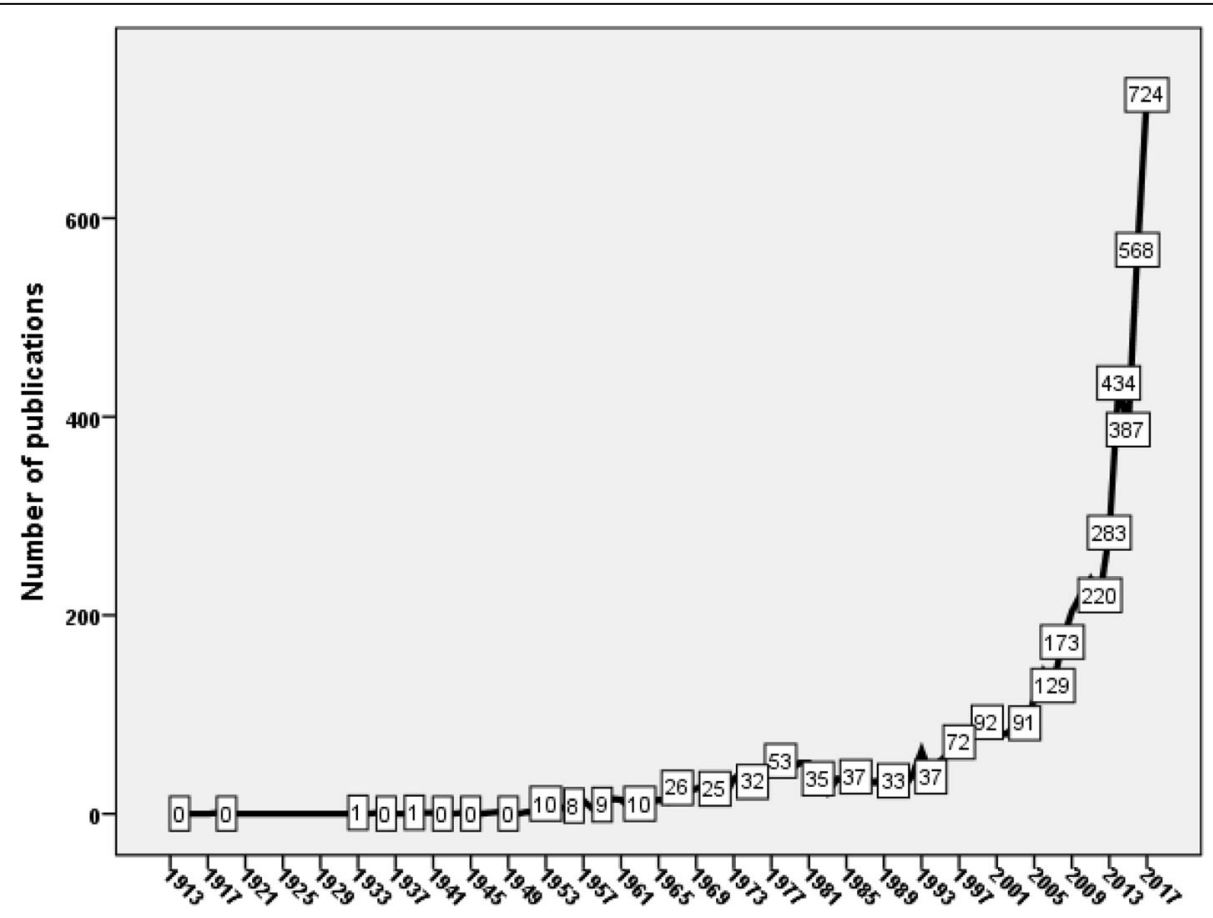

Fig. 1 Annual growth of publications in transgender health (1900-2017) 
Table 1 Top 10 cited articles in transgender health

\begin{tabular}{|c|c|c|c|c|}
\hline Title & Year & Source title & Cited by & $\begin{array}{l}\text { Document } \\
\text { Type }\end{array}$ \\
\hline $\begin{array}{l}\text { "Standards of Care for the Health of Transsexual, Transgender, } \\
\text { and Gender-Nonconforming People, Version 7" [95] }\end{array}$ & 2012 & International Journal of Transgenderism & 524 & Article \\
\hline $\begin{array}{l}\text { "Endocrine treatment of transsexual persons: An endocrine } \\
\text { society clinical practice guideline" [96] }\end{array}$ & 2009 & $\begin{array}{l}\text { Journal of Clinical Endocrinology and } \\
\text { Metabolism }\end{array}$ & 458 & Review \\
\hline $\begin{array}{l}\text { "A sex difference in the human brain and its relation to } \\
\text { transsexuality" [97] }\end{array}$ & 1995 & Nature & 430 & Article \\
\hline $\begin{array}{l}\text { "HIV prevalence, risk behaviors, health care use, and mental health } \\
\text { status of transgender persons: Implications for public health } \\
\text { intervention" [98] }\end{array}$ & 2001 & American Journal of Public Health & 412 & Article \\
\hline $\begin{array}{l}\text { "Attempted suicide among transgender persons: The influence of } \\
\text { gender-based discrimination and victimization" [99] }\end{array}$ & 2006 & Journal of Homosexuality & 342 & Article \\
\hline $\begin{array}{l}\text { "Estimating HIV prevalence and risk behaviors of transgender persons } \\
\text { in the United States: A systematic review" [85] }\end{array}$ & 2008 & AIDS and Behavior & 339 & Review \\
\hline $\begin{array}{l}\text { "Gender violence: Transgender experiences with violence and } \\
\text { discrimination" [100] }\end{array}$ & 2001 & Journal of Homosexuality & 326 & Article \\
\hline $\begin{array}{l}\text { "Suicide and suicide risk in lesbian, gay, bisexual, and transgender } \\
\text { populations: Review and recommendations" [101] }\end{array}$ & 2011 & Journal of Homosexuality & 304 & Review \\
\hline $\begin{array}{l}\text { Worldwide burden of HIV in transgender women: A systematic review } \\
\text { and meta-analysis [40] }\end{array}$ & 2013 & The Lancet Infectious Diseases & 282 & Article \\
\hline $\begin{array}{l}\text { Lesbian, gay, bisexual, and transgender-related content in } \\
\text { undergraduate medical education [102] }\end{array}$ & 2011 & $\begin{array}{l}\text { Journal of the American Medical } \\
\text { Association }\end{array}$ & 260 & Article \\
\hline
\end{tabular}

Eastern Europe had limited contribution to literature in transgender health.

\section{Highly active countries}

The top ten active countries were shown in Table 2 along with the impact of their publications measured as the number of citations per article. Documents with authors from the Netherlands had the highest impact with an average number of citations of 35 per document followed by those from Belgium (17.1), and those from the USA (15.6). Authors in top ten active countries contributed to 4377 (75.1\%) documents. Authors from the USA participated in publishing 2494 (43.2\%) documents. The most active countries included one country from Latin America; Brazil (114; 2.0\%). None of the countries in top ten list were from South - East Asia or Africa or the Middle East or Eastern Europe.

\section{Analysis of publication from the US}

Further analysis of publications by US researchers indicated that authors from the East coast of the USA (Maine, New Hampshire, Massachusetts, Rhode Island, Connecticut, New York, New Jersey, Delaware, Maryland, Virginia, North Carolina, South Carolina, Georgia, and Florida) participated in publishing 810 (32.5\%) documents while those from the West coast (California, Oregon, and Washington) participated in publishing 760 (30.5\%) documents. The contribution of authors from the Midwest region (Illinois, Indiana, Iowa, Kansas, Michigan, Minnesota, Missouri, Ohio, Nebraska, North Dakota, South Dakota, and
Wisconsin) was 650 (26.1\%) documents while those by authors from the Southwest region of the USA (Nevada, New Mexico, Utah, Arizona, Texas, and Colorado) was the least $(230 ; 9.2 \%)$. It should be noted that there is a certain degree of overlap in the number of publications due to research collaboration.

\section{Authorship analysis and active institutions/organizations}

Approximately 10,000 authors participated in publishing the retrieved documents, an average of 2.4 authors per document. Table 3 shows top ten active authors Professor Gooren, L.J.G. was the most active with 104 (2.4\%) publications. The most active authors were in the fields of endocrinology, plastic surgery, psychiatry/psychology, sexology, and public health. Five of the top ten active authors were from the USA, three were from the Netherlands, and two were from Belgium. When retrieved data were analyzed for most active institutions/organizations, the $V U$ University Medical Center in the Netherlands ranked first with 184 (3.2\%) publications followed by the University of California, San Francisco (USA) with 157 (2.7\%) publications. Seven institutions of the top ten list were in the USA, one was in Canada, one was in Belgium, and one was in the Netherlands (Table 4).

\section{Most active journals}

Retrieved documents were published in journals with different scopes. The top ten list included journals in the field of transgender /sexual medicine, public health, endocrinology, plastic surgery, and psychiatry (Table 5). 

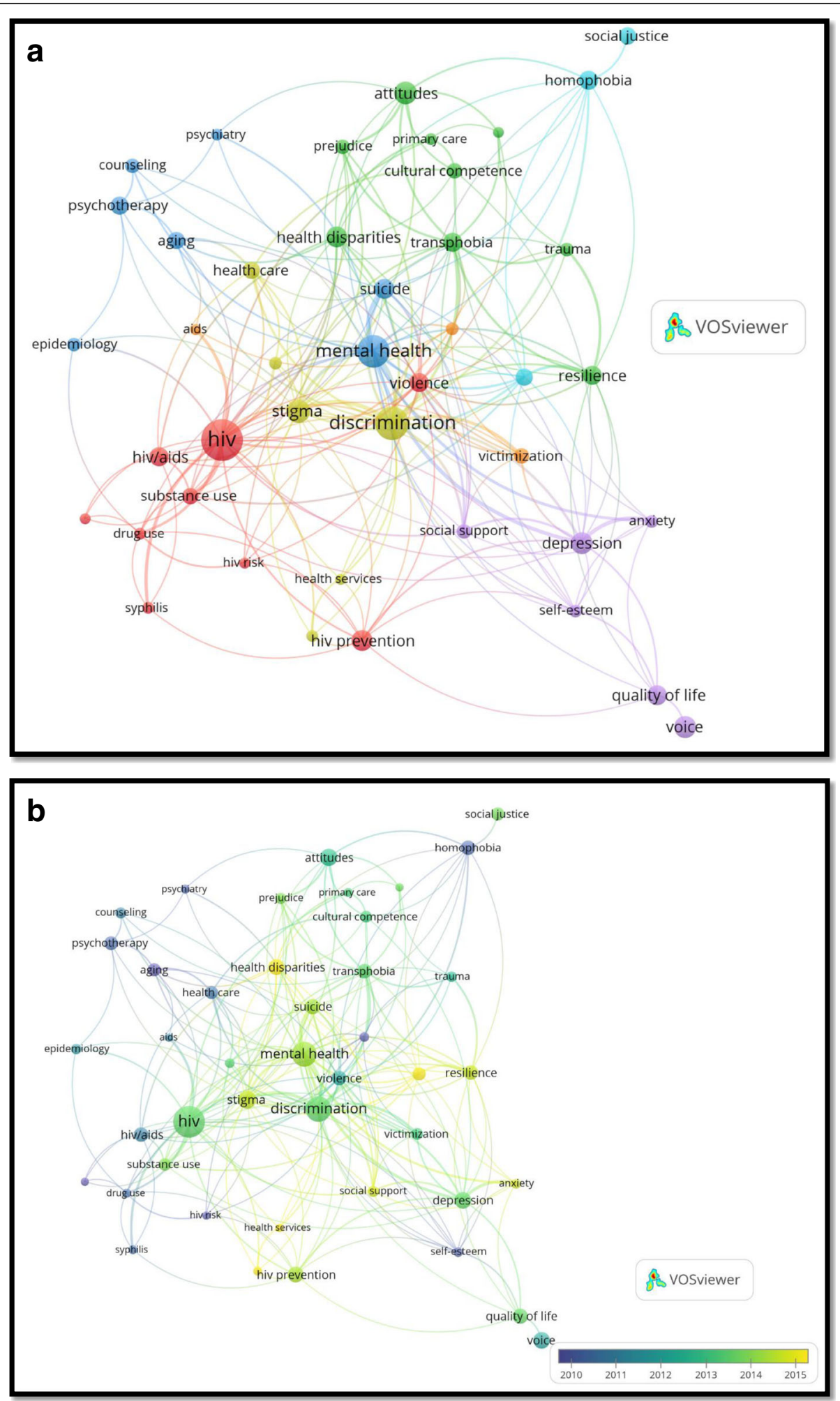

Fig. 2 a and $\mathbf{b}$ Network visualization map and overlay visualization of author keywords in transgender health (1900-2017). These figures were created using VOSVViewer program which is available for free download from the Leiden University [42, 43] 


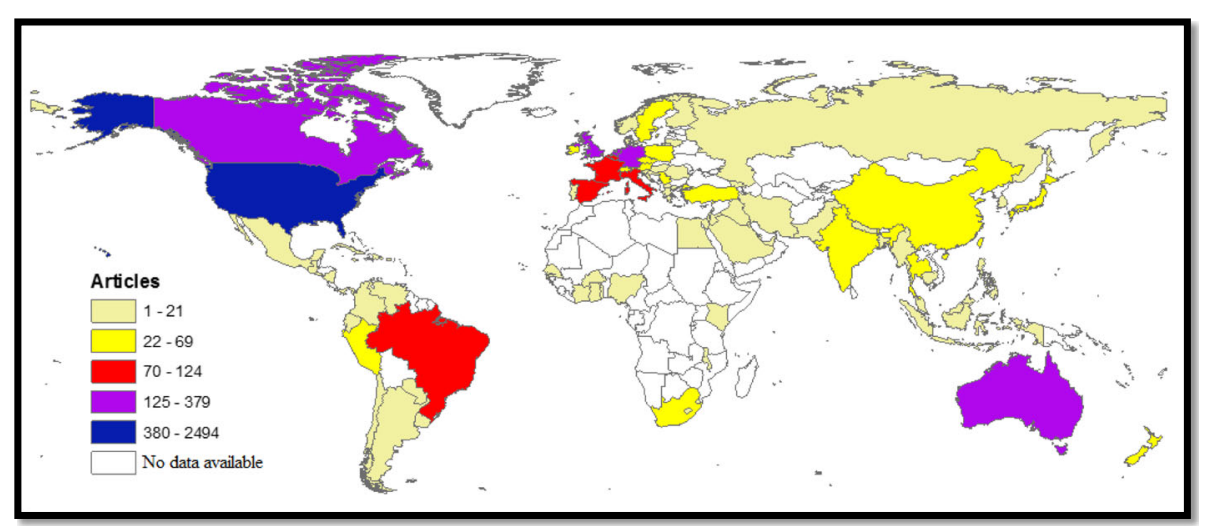

Fig. 3 Geographical distribution of peer-reviewed documents in transgender health (1900-2017). This map was created using a copy of ArcGIS 10.1 program [44] available at the Faculty of Engineering at An-Najah National University. The author has full access to the Engineering Laboratories and to ArcGIS program

The International Journal of Transgenderism ranked first with 280 (4.9\%) documents. However, documents in transgender health published in the American Journal of Public Health received the highest number of citations per article (53) followed by those published in Journal of Homosexuality (27). The majority of top 10 active journals were in the field of sexual medicine. One journal was in the field of public health, one was in plastic surgery, and one in the field of AIDS. Eight of most active journals were based in the USA while two were based in Europe.

\section{Discussion}

In this study, we aimed to assess and analyze growth and research trends of peer-reviewed publications in transgender health. Publications in transgender health showed a sharp rise after 2005. Several factors could be cited to explain the sharp rise in the number of publications. Of particular importance is the appearance of publications in transgender health in highly prestigious journals such as The Lancet and the

Table 2 Top ten active countries in transgender health research

\begin{tabular}{lllll}
\hline Country & Frequency & $\%$ & $\mathrm{C}$ & $\mathrm{C} / \mathrm{A}$ \\
& \multicolumn{5}{c}{$\mathrm{N=5772}$} & & \\
\hline United States & 2494 & 43.2 & 38982 & 15.6 \\
United Kingdom & 379 & 6.6 & 4231 & 11.2 \\
Canada & 321 & 5.6 & 4017 & 12.5 \\
Germany & 252 & 4.4 & 2431 & 9.6 \\
Netherlands & 247 & 4.3 & 8585 & 34.8 \\
Australia & 211 & 3.7 & 1968 & 9.3 \\
France & 124 & 2.1 & 551 & 4.4 \\
Belgium & 121 & 2.1 & 2069 & 17.1 \\
Brazil & 114 & 2.0 & 689 & 6.0 \\
Spain & 114 & 2.0 & 990 & 8.7 \\
\hline
\end{tabular}

C: number of citations

C/A: number of citations per article
American Journal of Public Health which encouraged researchers in various disciplines to get involved in this research topic. A potentially second reason is the findings that the number of transgender people is larger than expected even in epidemiological studies and surveys in non-western countries [48, 49]. A third possible reason is the active role of human rights and transgender groups which argued against stigma and discrimination faced by the transgender community [10, 50-54]. Furthermore, transphobia led many researchers and health organizations to address this issue in international forums in order to support the health and human rights of the transgender community [55-59].

The current study showed that mental health research dominated the field of transgender health. Most mental health issues faced by transgender people are due to cultural intolerance, social stigma, discrimination, violence, and victimization [60-64]. The social stress and stigma created higher prevalence of depression and suicidal ideation in transgender individuals compared with cisgender people $[65,66]$. Transgender individuals are subject to psychological stress [67] due to discrimination and social rejection. It should be emphasized that mental health issues in transgender persons are not due to transgender identity [9]. Studies indicated that a major cause of depression and suicidal ideation among transgender individuals is the stigma, trans-phobia, sexual assault, violence, and social de-evaluation $[68,69]$. The World Health Organization (WHO) is considering declassification of transgender and sexual orientation from mental health disease classification [70]. Such move by WHO was supported by the scientific community $[71,72]$. A key element in overcoming mental problems such as depression, anxiety, and stress in transgender persons is social support and acceptance [73, 
Table 3 Top ten active authors in the field of transgender health

\begin{tabular}{|c|c|c|c|c|}
\hline Rank & Name & Frequency & $\begin{array}{l}\% \\
N=5772\end{array}$ & Affiliation \\
\hline 1 st & Gooren, L.J.G. & 104 & 1.8 & VU University Medical Center, Department of Endocrinology, Amsterdam, Netherlands \\
\hline 2nd & Reisner, S.L. & 62 & 1.1 & Fenway Institute, Boston, United States \\
\hline $3 r d$ & Bockting, W. & 56 & 1.0 & New York State Psychiatric Institute, Division of Gender, New York, United States \\
\hline 4th & Hage, J.J. & 46 & 0.8 & $\begin{array}{l}\text { Antoni van Leeuwenhoek Ziekenhuis, Department of Plastic and Reconstructive Surgery, } \\
\text { Amsterdam, Netherlands }\end{array}$ \\
\hline 5th & T'Sjoen, G. & 43 & 0.7 & University Hospital of Ghent, Department of Endocrinology, Ghent, Belgium \\
\hline 6th & Cohen-Kettenis, P.T. & 35 & 0.6 & $\begin{array}{l}\text { VU University Medical Center, Department of Medical Psychology and Medical Social Work, } \\
\text { Amsterdam, Netherlands }\end{array}$ \\
\hline 7th & De Cuypere, G. & 30 & 0.5 & University Hospital of Ghent, Department of Sexology and Gender Problems, Ghent, Belgium \\
\hline 8th & Garofalo, R. & 26 & 0.5 & Children's Memorial Hospital, Division of Adolescent Medicine, Chicago, United States \\
\hline 9th & Operario, D. & 25 & 0.4 & Department of Behavior and Social Sciences, Brown University, Providence, United States \\
\hline 10th & Nemoto, T. & 24 & 0.4 & Public Health Institute Oakland, Oakland, United States \\
\hline
\end{tabular}

74]. Despite discrimination, stigma, and victimization, the transgender community had shown remarkable extent of resilience and survival [66].

The current study showed that global contribution to transgender health research was limited to the regions of Americas, Europe, South-East Asia, and Western Pacific. It was not surprising that countries such as USA, Brazil, Philippines, and Thailand showed relatively high research activity. Unofficial reports indicated large numbers of transgender people in these countries. The number of publications from African and Mediterranean regions was limited. This could be attributed to the limited number of transgender people in both regions or due to limited research capacity in these regions. African region is considered the highest in terms of numbers of people with AIDS [75, 76] which could be due to the presence of infected female sex workers, lack of healthcare, and preventive measures but not due to transgender identity [77-79]. For the Mediterranean region, the cultural and religious background does not allow for sexual freedom and, therefore, data regarding transgender people, $\mathrm{HIV}$, gay, lesbians, and bisexuals are relatively limited and might be inaccurate in that region [80-84].

The current study indicated that literature in transgender health discussed several aspects of STD including HIV/AIDS. A study carried out in the USA found that $28 \%$ of transgender individuals had HIV and $21 \%$ had other sexually transmitted diseases [40, 85]. Lack of preventive health practices and lack of screening are potential causes for the high prevalence of STD among transgender individuals [86-89].

Transgender health is a global issue and publications in this field is growing as a separate field or as part of research in LGBTQ community as an overall. The author did his best to collect all peer-reviewed documents in transgender health to endorse research and encourage other researchers and clinicians to get engaged in this field. However, the author acknowledges the fact that not all publications and health journals are indexed in Scopus and therefore, some publications in this field might be missed. This is a common limitation in bibliometric studies [31, 36, 90-93].

Table 4 Top ten active institutions/organizations in transgender health

\begin{tabular}{llll}
\hline Institution/organization & Frequency & $\%(N=5772)$ & Country \\
\hline VU University Medical Center & 184 & 3.2 & Netherlands \\
University of California, San Francisco & 157 & 2.7 & USA \\
Harvard Medical University & 139 & 1.4 & USA \\
University of California, Los Angeles & 105 & 1.5 & 1.4 \\
University Hospital of Ghent & 88 & 1.3 & USA \\
University of Toronto & 79 & 1.2 & Canada \\
Johns Hopkins University & 76 & 1.0 & USA \\
Columbia University in the City of New York & 68 & 1.0 & USA \\
Children's Hospital Boston & 59 & 58 & USA \\
University of Washington, Seattle & & USA
\end{tabular}


Table $\mathbf{5}$ Top ten active journals in publishing in documents in transgender health research

\begin{tabular}{|c|c|c|c|c|c|}
\hline Name of the Journal & Frequency & $\%(N=4417)$ & C & $\mathrm{C} / \mathrm{A}$ & Country \\
\hline International Journal of Transgenderism & 280 & 4.9 & 3186 & 11.4 & USA \\
\hline Archives of Sexual Behavior & 216 & 3.7 & 4994 & 23.1 & USA \\
\hline Journal of Sexual Medicine & 86 & 1.5 & 1512 & 17.6 & USA \\
\hline Plastic and Reconstructive Surgery & 79 & 1.4 & 1062 & 13.4 & USA \\
\hline Journal of Homosexuality & 75 & 1.3 & 2048 & 27.3 & USA \\
\hline American Journal of Public Health & 65 & 1.1 & 3475 & 53.5 & USA \\
\hline Journal of Gay and Lesbian Social Services & 53 & 0.9 & 641 & 12.1 & USA \\
\hline AIDS And Behavior & 50 & 0.9 & 929 & 18.6 & Netherlands \\
\hline LGBT Health & 58 & 1.0 & 250 & 4.3 & USA \\
\hline Journal Of Lgbt Issues In Counseling & 41 & 0.7 & 382 & 9.3 & USA \\
\hline Journal Of Sex Research & 41 & 0.7 & 570 & 13.9 & UK \\
\hline
\end{tabular}

C: number of citations

$\mathrm{C} / \mathrm{A}$ : number of citations per article

\section{Conclusion}

The results of the current study showed (1) dramatic increase in the number of publications in transgender health in the last decade; (2) the bulk of literature in transgender health focused on HIV/AIDS, mental health, and discrimination; (3) regions of Africa, Middle East, and East Europe had the least research contribution to transgender health; (4) most active and leading authors and institutions in transgender health were restricted to northern America and Europe; and (5) $h$-index of peer reviewed documents in transgender health was less than 100 but relatively higher than that recorded for other subjects [34, 94].

\section{Additional file}

Additional file 1: Research strategy in transgender health (1900-2017) (DOCX $13 \mathrm{~kb}$ )

\section{Abbreviations}

HIV/AIDS: Human Immunodeficiency Virus / Acquired Immunodeficiency Syndrome; LGBTQ: Lesbian, gay, bisexual, transgender, and queer; WHO: World Health Organization

\section{Acknowledgments}

None.

\section{Funding}

None.

\section{Availability of data and materials}

All data present in this article can be retrieved from Scopus using keywords listed in the methodology.

\section{Authors' contributions}

WS: concept, data extraction, analysis and presentation, manuscript preparation, and manuscript submission and follow up. The author read and approved the final manuscript.

Ethics approval and consent to participate Not applicable.
Consent for publication

Not applicable.

\section{Competing interests}

The author declares that he has no competing interests.

\section{Publisher's Note}

Springer Nature remains neutral with regard to jurisdictional claims in published maps and institutional affiliations.

Received: 10 October 2017 Accepted: 14 March 2018

Published online: 21 March 2018

\section{References}

1. Graham R, Berkowitz B, Blum R, Bockting W, Bradford J, de Vries B, Garofalo R, Herek G, Howell E, Kasprzyk D. The health of lesbian, gay, bisexual, and transgender people: building a foundation for better understanding. Washington: Institute of Medicine; 2011.

2. Schilt K, Westbrook L. Doing gender, doing heteronormativity: "gender Normals," transgender people, and the social maintenance of heterosexuality. Gend. Soc. 2009;23(4):440-64.

3. Rawson K, Williams C. Transgender*: the rhetorical landscape of. Present Tense. 2014;3(2)

4. Institute W. How many adults identify as transgender in the unites states. 2016.

5. Winter S. Lost in transition: transgender people. Rights and HIV vulnerability in the Asia-Pacific region. Focus. 2012;69.

6. Network APT: Blueprint for the provision of comprehensive care for trans people and trans communities in Asia and the Pacific. 2015.

7. UNAIDS. The gap report 2014 (transgender people). Geneva; 2014.

8. Winter S, Diamond M, Green J, Karasic D, Reed T, Whittle S, Wylie K Transgender people: health at the margins of society. Lancet. 2016; 388(10042):390-400.

9. Reisner SL, Poteat T, Keatley J, Cabral M, Mothopeng T, Dunham E, Holland CE, Max R, Baral SD. Global health burden and needs of transgender populations: a review. Lancet. 2016;388(10042):412-36.

10. Winter S, Settle E, Wylie K, Reisner S, Cabral M, Knudson G, Baral S. Synergies in health and human rights: a call to action to improve transgender health. Lancet. 2016;388(10042):318-21.

11. Taylor JK, Haider-Markel DP, editors. Transgender rights and politics: Groups, Issue framing, and policy adoption. University of Michigan Press; 2014.

12. Powell T, Shapiro S, Stein E. Transgender rights as human rights. AMA J. Ethics. 2016;18(11):1127.

13. Kirby T. Sari Reisner-making transgender health visible. Lancet. 2016; 388(10042):332.

14. Lane R. Sam Winter and Kevan Wylie: pioneers in transgender health. Lancet. 2016;388(10042):331. 
15. Lo S, Horton R. Transgender health: an opportunity for global health equity. Lancet. 2016;388(10042):316-8.

16. Reed T. GIRES: e-learning for transgender health training. Lancet. 2016; 388(10042):333.

17. Fraser B. Peru's transgender community: the battle for rights. Lancet (London, England). 2016;388(10042):324-5.

18. Green J. Transgender: why should we care? Lancet. 2016;388(10042):334-5.

19. Civilities, What does the acronym LGBTQ stand for? https://www. washingtonpost.com/news/arts-and-entertainment/wp/2014/05/23/civilitieswhat-does-the-acronym-lgbtq-stand-for/?utm_term=.ae35317focec. Accessed 1 Mar 2018.

20. Stinchcombe A, Smallbone J, Wilson K, Kortes-Miller K. Healthcare and endof-life needs of lesbian, gay, bisexual, and transgender (LGBT) older adults: a scoping review. Geriatrics. 2017;2(1):13.

21. Bry $L$, Mustanski B, Garofalo R, Burns MN. Resilience to discrimination and rejection among young sexual minority males and transgender females: a qualitative study on coping with minority stress. J Homosex. 2017;13:1-22. https://doi.org/10.1080/00918369.2017.1375367.

22. Gurung S, Ventuneac A, Rendina HJ, Savarese E, Grov C, Parsons JT. Prevalence of military sexual trauma and sexual orientation discrimination among lesbian, gay, bisexual, and transgender military personnel: a descriptive study. Sex. Res. Soc. Policy. 2018;15(1):74-82.

23. Kattari SK, Walls NE, Whitfield DL, Langenderfer Magruder L. Racial and ethnic differences in experiences of discrimination in accessing social services among transgender/gender-nonconforming people. J Ethnic Cult Divers Soc Work. 2017;26(3):217-35.

24. Liu H, Wilkinson L. Marital status and perceived discrimination among transgender people. J Marriage Fam. 2017;79(5):1295-313.

25. McCann E, Brown M. Discrimination and resilience and the needs of people who identify as transgender: a narrative review of quantitative research studies. J Clin Nurs. 2017;26(23-24):4080-93.

26. Rodriguez A, Agardh A, Asamoah BO. Self-reported discrimination in healthcare settings based on Recognizability as transgender: a cross-sectional study among transgender U.S. citizens. Arch Sex Behav. 2017:1-13.

27. Tabaac A, Perrin PB, Benotsch EG. Discrimination, mental health, and body image among transgender and gender-non-binary individuals: constructing a multiple mediational path model. J Gay Lesbian Social Services. 2018;30(1):1-16.

28. Thoroughgood CN, Sawyer KB, Webster JR. What lies beneath: how paranoid cognition explains the relations between transgender employees' perceptions of discrimination at work and their job attitudes and wellbeing. J Vocat Behav. 2017;103:99-112

29. Williams CC, Curling D, Steele LS, Gibson MF, Daley A, Green DC, Ross LE, Depression and discrimination in the lives of women, transgender and gender liminal people in Ontario, Canada. Health Soc. Care Community. 2017;25(3):1139-50.

30. Sweileh WM, Shraim NY, Al-Jabi SW, Sawalha AF, AbuTaha AS, Zyoud SH. Bibliometric analysis of global scientific research on carbapenem resistance (1986-2015). Ann Clin Microbiol Antimicrob. 2016;15(1):56.

31. Sweileh WM. Global research trends of World Health Organization's top eight emerging pathogens. Glob Health. 2017;13(1)

32. Sweileh WM, Sawalha AF, Al-Jabi S, Zyoud SH. Bibliometric analysis of literature on antifungal triazole resistance: 1980 - 2015. Germs. 2017;7(1):19-27.

33. Sweileh WM, Sawalha AF, Al-Jabi SW, Zyoud SH, Shraim NY, Abu-Taha AS. A bibliometric analysis of literature on malaria vector resistance: (1996 - 2015). Glob Health. 2016;12(1):76.

34. Sweileh WM. Bibliometric analysis of literature on female genital mutilation: (1930-2015). Reprod Health. 2016;13(1):130.

35. Sweileh WM, AbuTaha AS, Sawalha AF, Al-Khalil S, Al-Jabi SW, Zyoud SH. Bibliometric analysis of worldwide publications on multi-, extensively, and totally drug - resistant tuberculosis (2006-2015). Multidiscip Respir Med. 2016;11:45.

36. Sweileh WM, AbuTaha AS, Sawalha AF, Al-Khalil S, Al-Jabi SW, Zyoud SH. Bibliometric analysis of worldwide publications on multi-, extensively, and totally drug - resistant tuberculosis (2006-2015). Multidiscip Respir Med. 2017;11(1):1-16.

37. Sweileh WM, Al-Jabi SW, Sawalha AF, AbuTaha AS, Zyoud SH. Bibliometric analysis of medicine-related publications on poverty (2005-2015). SpringerPlus. 2016;5(1):1888.

38. Falagas ME, Pitsouni El, Malietzis GA, Pappas G. Comparison of PubMed, Scopus, web of science, and Google scholar: strengths and weaknesses. FASEB J. 2008;22(2):338-42.

39. Stephenson R, Riley E, Rogers E, Suarez N, Metheny N, Senda J, Saylor KM, Bauermeister JA. The sexual health of transgender men: a scoping review. J Sex Res. 2017;54(4-5):424-45.
40. Baral SD, Poteat T, Strömdahl S, Wirtz AL, Guadamuz TE, Beyrer C. Worldwide burden of HIV in transgender women: a systematic review and meta-analysis. Lancet Infect Dis. 2013;13(3):214-22.

41. Van Eck NJ, Waltman L. Software survey: VOSviewer, a computer program for bibliometric mapping. Scientometrics. 2010;84(2):523-38.

42. VOSviewer version 1.6.7. http://www.vosviewer.com/download. Accessed 1 Mar 2018

43. van Eck NJ, Waltman L. VOSviewer manual, Manual for VOSviewer version; 2011. p. 13.

44. ArcGIS 10.1 Available Soon. https://blogs.esri.com/esri/arcgis/2012/06/11/ arcgis-10-1-available-soon/. Accessed 1 Mar 2018.

45. Hirsch JE. An index to quantify an individual's scientific research output. Proc Natl Acad Sci U S A. 2005;102(46):16569-72.

46. Oehmig O. Beitrag zur Lehre vom Transvestismus. Zeitschrift für die gesamte Neurologie und Psychiatrie. 1913;15(1):190-204.

47. Coleman E, Bockting W, Botzer M, Cohen-Kettenis P, DeCuypere G, Feldman J, Fraser L, Green J, Knudson G, Meyer WJ, et al. Standards of Care for the Health of transsexual, transgender, and gender-nonconforming people, version 7. Int J Transgenderism. 2012;13(4):165-232.

48. Arcelus J, Bouman WP, Van Den Noortgate W, Claes L, Witcomb G, Fernandez-Aranda F. Systematic review and meta-analysis of prevalence studies in transsexualism. Eur. Psychiatry. 2015;30(6):807-15.

49. Collin L, Reisner SL, Tangpricha V, Goodman M. Prevalence of transgender depends on the "case" definition: a systematic review. J. Sex. Med. 2016; 13(4):613-26.

50. Powell T, Shapiro S, Stein E. Transgender rights as human rights. AMA J Ethics. 2016;18(11):1126-31.

51. Marks SM. Global recognition of human rights for lesbian, gay, bisexual, and transgender people. Health Hum. Rights. 2006;9(1):33-42.

52. Reed LR. Transsexuals and European human rights law. J Homosex. 2005; 48(3-4):49-90.

53. Wilkinson C, Langlois AJ. Special issue: not such an international human rights norm? Local resistance to lesbian, gay, bisexual, and transgender rights—-preliminary comments. J Hum Rights. 2014;13(3):249-55.

54. Cobos DG, Jones J. Moving forward: transgender persons as change agents in health care access and human rights. J Assoc Nurses AIDS Care. 2009;20(5):341-7.

55. Costa PA, Davies M. Portuguese Adolescents' attitudes toward sexual minorities: transphobia, homophobia, and gender role beliefs. J Homosex. 2012;59(10):1424-42.

56. DePalma R, Jennett M. Homophobia, transphobia and culture: deconstructing heteronormativity in English primary schools. Intercult Educ. 2010;21(1):15-26.

57. Mizock L, Mueser KT. Employment, mental health, internalized stigma, and coping with transphobia among transgender individuals. Psychology of Sexual Orientation and Gender Diversity. 2014:1 (2):146-58.

58. Nagoshi JL, Adams KA, Terrell HK, Hill ED, Brzuzy S, Nagoshi CT. Gender differences in correlates of homophobia and transphobia. Sex Roles. 2008; 59(7-8):521-31.

59. Sugano $E$, Nemoto $T$, Operario $D$. The impact of exposure to transphobia on HIV risk behavior in a sample of transgendered women of color in San Francisco. AIDS Behav. 2006:10(2):217-25.

60. Page S, Burgess J, Davies-Abbott I, Roberts D, Molderson J. Transgender, mental health, and older people: an appreciative approach towards working together. Issues in Mental Health Nursing. 2016;37(12):903-11.

61. Carmel TC, Erickson-Schroth L. Mental health and the transgender population. J Psychosoc Nurs Ment Health Serv. 2016;54(12):44-8.

62. Jaffee KD, Shires DA, Stroumsa D. Discrimination and delayed health care among transgender women and men. Med Care. 2016;54(11):1010-6.

63. Carmel TC, Erickson-Schroth L. Mental health and the transgender population. Psychiatr Ann. 2016;46(6):346-9.

64. Erickson-Schroth L, Carmel TC. Transgender mental health. Psychiatr Ann. 2016:46(6):330-1.

65. Fredriksen-Goldsen KI, Cook-Daniels L, Kim H-J, Erosheva EA, Emlet CA, HoyEllis CP, Goldsen J, Muraco A. Physical and mental health of transgender older adults: an at-risk and underserved population. The Gerontologist. 2013;54(3):488-500.

66. Grant JM, Mottet L, Tanis JE, Harrison J, Herman J, Keisling M. Injustice at every turn: a report of the National Transgender Discrimination Survey: National Center for Transgender Equality; 2011.

67. Nuttbrock L, Rosenblum A, Blumenstein R. Transgender identity affirmation and mental health. International Journal of Transgenderism. 2002;6(4):97-03. 
68. Mizock L, Mueser KT. Employment, mental health, internalized stigma, and coping with transphobia among transgender individuals. Psychology of Sexual Orientation and Gender Diversity. 2014;1(2):146.

69. Bradford J, Reisner SL, Honnold JA, Xavier J. Experiences of transgenderrelated discrimination and implications for health: results from the Virginia transgender health initiative study. Am J Public Health. 2013;103(10):1820-9.

70. Cochran SD, Drescher J, Kismödi E, Giami A, García-Moreno C, Atalla E, Marais A, Vieira EM, Reed GM. Proposed declassification of disease categories related to sexual orientation in the international statistical classification of diseases and related health problems (ICD-11). Bull World Health Organ. 2014;92(9):672-9.

71. Canady VA. Study supports WHO move to declassify transgender identity as mental disorder. Ment Heal Wkly. 2016;26(31):1-4.

72. Robles R, Fresán A, Vega-Ramírez H, Cruz-Islas J, Rodríguez-Pérez V, Domínguez-Martínez T, Reed GM. Removing transgender identity from the classification of mental disorders: a Mexican field study for ICD-11. Lancet Psychiatry. 2016;3(9):850-9.

73. Pflum SR, Testa RJ, Balsam KF, Goldblum PB, Bongar B. Social support, trans community connectedness, and mental health symptoms among transgender and gender nonconforming adults. Psychology of sexual orientation and gender diversity. 2015;2(3):281.

74. Budge SL, Adelson JL, Howard KA. Anxiety and depression in transgender individuals: the roles of transition status, loss, social support, and coping. J Consult Clin Psychol. 2013;81(3):545.

75. Maartens G, Celum C, Lewin SR. HIV infection: epidemiology, pathogenesis, treatment, and prevention. Lancet. 2014;384(9939):258-71.

76. Idele P, Gillespie A, Porth T, Suzuki C, Mahy M, Kasedde S, Luo C. Epidemiology of HIV and AIDS among adolescents: current status, inequities, and data gaps. J Acquir Immune Defic Syndr. 2014;66:S144-53.

77. Maleke K, Makhakhe N, Peters RPH, Jobson G, De Swardt G, Daniels J, Lane T, McIntyre JA, Imrie J, Struthers H. HIV risk and prevention among men who have sex with men in rural South Africa. African J AIDS Res. 2017;16(1):31-8.

78. Abara WE, Garba I. HIV epidemic and human rights among men who have sex with men in sub-Saharan Africa: implications for HIV prevention, care, and surveillance. Glob. Public Health. 2017;12(4):469-82.

79. Pitpitan EV, Kalichman SC, Eaton LA, Watt MH, Sikkema KJ, Skinner D, Pieterse D, Cain D. Men (and women) as "sellers" of sex in alcohol-serving venues in cape town, South Africa. Prev Sci. 2014;15(3):296-308.

80. Ilkkaracan P. Commentary: sexual health and human rights in the Middle East and North Africa: progress or backlash? Glob. Public Health. 2015;10(2):268-70

81. Ilkkaracan P. Deconstructing sexuality in the Middle East: challenges and discourses: Routledge; 2016.

82. Gökengin D, Doroudi F, Tohme J, Collins B, Madani N. HIV/AIDS: trends in the Middle East and North Africa region. Int J Infect Dis. 2016;44:66-73.

83. Kaplan RL, El Khoury C. The elephants in the room: sex, HIV and LGBT populations in MENA. Intersectionality in Lebanon: comment on "improving the quality and quantity of HIV data in the Middle East and North Africa: key challenges and ways forward.". Int J Health Policy Manag. 2016;6(8):4779. https://doi.org/10.15171/ijhpm.2016.149.

84. Setayesh H, Roudi-Fahimi F, El Feki S, Ashford LS. HIV and AIDS in the Middle East and North Africa. Washington: Population Reference Bureau; 2014.

85. Herbst JH, Jacobs ED, Finlayson TJ, McKleroy VS, Neumann MS, Crepaz N, Team HAPRS. Estimating HIV prevalence and risk behaviors of transgender persons in the United States: a systematic review. AIDS Behav. 2008;12(1):1-17.

86. Garofalo R, Deleon J, Osmer E, Doll M, Harper GW. Overlooked, misunderstood and at-risk: exploring the lives and HIV risk of ethnic minority male-to-female transgender youth. J Adolesc Health. 2006;38(3):230-6.

87. Crosby RA, Pitts NL. Caught between different worlds: how transgendered women may be "forced" into risky sex. J. Sex Res. 2007:44(1):43-8.

88. Sevelius JM, Reznick OG, Hart SL, Schwarcz S. Informing interventions: the importance of contextual factors in the prediction of sexual risk behaviors among transgender women. AIDS Educ. Prev. 2009;21(2):113-27.

89. Ramirez-Valles J, Garcia D, Campbell RT, Diaz RM, Heckathorn DD. HIV infection, sexual risk behavior, and substance use among Latino gay and bisexual men and transgender persons. Am J Public Health. 2008;98(6):1036-42.

90. Sweileh WM. Bibliometric analysis of literature on female genital mutilation: (1930-2015) female genital mutilation. Reprod Health. 2016;13(1):1-13.

91. Sweileh WM. Bibliometric analysis of medicine - related publications on refugees, asylum-seekers, and internally displaced people: 2000 - 2015. BMC International Health and Human Rights. 2017;17(1)

92. Sweileh WM. Bibliometric analysis of literature on toxic epidermal necrolysis and Stevens-Johnson syndrome: 1940 - 2015. Orphanet J. Rare Dis. 2017;12(1):1-15.
93. Sweileh WM, Al-Jabi SW, AbuTaha AS, Zyoud SH, Anayah FMA, Sawalha AF. Bibliometric analysis of worldwide scientific literature in mobile - health: 2006-2016. BMC Med. Inform. Decis. Mak. 2017;17(1)

94. Sweileh WM, Al-Jabi SW, AbuTaha AS, Sa'ed HZ, Anayah FM, Sawalha AF: Bibliometric analysis of worldwide scientific literature in mobile-health: 2006-2016. BMC Medical Informatics and Decision Making 2017, 17(1):72.

95. Coleman E, Bockting W, Botzer M, Cohen-Kettenis P, DeCuypere G, Feldman J, Fraser L, Green J, Knudson G, Meyer WJ. Standards of care for the health of transsexual, transgender, and gender-nonconforming people, version 7. International Journal of Transgenderism. 2012;13(4):165-232.

96. Hembree WC, Cohen-Kettenis P, Delemarre-Van De Waal HA, Gooren LJ, Meyer WJ III, Spack NP, Tangpricha V, Montori VM. Endocrine treatment of transsexual persons: an Endocrine Society clinical practice guideline. J. Clin. Endocrinol. Metab. 2009;94(9):3132-54.

97. Zhou J-N, Hofman MA, Gooren LJ, Swaab DF. A sex difference in the human brain and its relation to transsexuality. Nature. 1995;378(6552):68.

98. Clements-Nolle K, Marx R, Guzman R, Katz M. HIV prevalence, risk behaviors, health care use, and mental health status of transgender persons: implications for public health intervention. Am J Public Health. 2001;91(6):915.

99. Clements-Nolle K, Marx R, Katz M. Attempted suicide among transgender persons: the influence of gender-based discrimination and victimization. J Homosex. 2006:51(3):53-69.

100. Lombardi EL, Wilchins RA, Priesing D, Malouf D. Gender violence: transgender experiences with violence and discrimination. J Homosex. 2002;42(1):89-101.

101. Haas AP, Eliason M, Mays VM, Mathy RM, Cochran SD, D'Augelli AR, Silverman MM, Fisher PW, Hughes T, Rosario M. Suicide and suicide risk in lesbian, gay, bisexual, and transgender populations: review and recommendations. J Homosex. 2010;58(1):10-51.

102. Obedin-Maliver J, Goldsmith ES, Stewart L, White W, Tran E, Brenman S, Wells M, Fetterman DM, Garcia G, Lunn MR. Lesbian, gay, bisexual, and transgender-related content in undergraduate medical education. JAMA. 2011;306(9):971-7.

\section{Submit your next manuscript to BioMed Central and we will help you at every step:}

- We accept pre-submission inquiries

- Our selector tool helps you to find the most relevant journal

- We provide round the clock customer support

- Convenient online submission

- Thorough peer review

- Inclusion in PubMed and all major indexing services

- Maximum visibility for your research

Submit your manuscript at www.biomedcentral.com/submit
Biomed Central 